\title{
Labour in Global Production Networks: \\ Workers and Unions in Mining Engineering Work
}

\author{
Authors \\ Patricia Todd \\ Senior Honorary Research Fellow \\ Management and Organisations \\ University of Western Australia Business School \\ Crawley, Western Australia \\ Australia \\ Bradon Ellem \\ Professor of Employment Relations \\ Work and Organisational Studies \\ University of Sydney Business School \\ Sydney, New South Wales \\ Australia \\ Caleb Goods ${ }^{1}$ \\ Research Fellow \\ Management and Organisations \\ University of Western Australia Business School \\ Crawley, Western Australia \\ Australia

\begin{abstract}
Al Rainnie
Honorary Professor

Industrial Relations Research Centre

University of New South Wales

Sydney, New South Wales

Australia

Leigh Smith

Department of Law

Curtin University, Western Australia
\end{abstract} \\ Australia
}

${ }^{1}$ Corresponding author caleb.goods@uwa.edu.au 


\title{
Labour in Global Production Networks: Workers and Unions in Mining Engineering Work
}

\begin{abstract}
Understanding the role of labour, underplayed in Global Production Networks (GPN) theory, has guided this research on the mining engineering services sector. During our project, the global mining industry entered a downturn. Asking how mining and engineering firms responded to the downturn is a specific variant of wider questions about the place of labour in GPNs and whether labour can shape the GPNs of which it is part. Based on interviews with union officials, workers and management in Australia, we show that cost-cutting by global mining companies impacted heavily on the mining engineering sector, pressuring global and local firms. Labour - be it the work process or workers themselves - was central to how firms reacted. The agency of workers and their union was deeply constrained because of the power of companies in GPNs and the nature of the national state and local economies, areas in need of further theoretical development.
\end{abstract}

\section{Key words}

Global production networks, labour, labour process, mining, engineering, unions.

Typically, labour relations scholars have not much engaged with global production network (GPN) analysis, nor has the otherwise fertile body of work around supply chains and GPNs paid much attention to labour, be it as object or subject (see Coe and Yeung, 2015 for a comprehensive statement). We accept that GPN analysis is a significant conceptual 
development building on the typically more linear supply chain theories and important but largely 'labour free' global value chain analysis and argue that GPN analysis is critical for understanding the nature of work and employment relations. More than this though, we set out to examine labour's role in GPNs.

To begin to answer the call which Coe and Yeung, among others, have made for empirical accounts of labour in GPNs, our research project asked how employment relations in the mining engineering services sector in Australia were shaped and, more specifically, what role labour, as subject and object, played in these GPNs. Not only can GPN analysis shed light on these questions but a focus on local accounts of employment relations builds a fuller explanation of the nature of the global relationships in these and other sectors. We suggest that, in globalised sectors, labour, national regulation and regional economies are integral to the nature of GPNs.

To take these steps in deepening GPN theory, we begin by explaining the importance of, and gaps in, GPN analysis before moving to what is a rich empirical context for such an investigation, the global mining industry and its local engineering suppliers in Australia.

\section{Production Networks and Labour}

In seeking to understand global supply chains and the social relations of work, scholars have developed a series of related but distinct frameworks, from Global Commodity Chains (GCCs) to Global Value Chains (GVCs) and now GPNs, which, their proponents suggest, are the most comprehensive of approaches to explaining global economic development. The fullest, most recent account of the GPN approach is Coe and Yeung's theorisation where they define a GPN 'as an organizational arrangement, comprising interconnected economic and non-economic 
actors, coordinated by a global lead firm, and producing goods or services across multiple geographical locations for worldwide markets' (Coe and Yeung, 2015: 2).

How does Coe and Yeung's recent work, styled as GPN 2.0, address our central concerns with labour as a source of value and as an agent within GPNs? Coe and Yeung see GPNs as systems of labour as much as systems of value creation and circulation. They note that:

many accounts remain silent, however, on how the workforces that underpin global production network activities are produced and reproduced through the activities of a wide range of organisations, of which the key actors in much research, firms and states, are but two of several (also trade unions, households etc.) (Coe and Yeung, 2015: 191).

Coe and Yeung do not develop their critique much beyond including labour as one of five 'extra firm actors' (along with the state) and cover the subject in a little over one third of a page (2015: 49). Others also argue that labour should be central to GPN analysis. Cumbers et al. (2010) do so succinctly: labour is important in the abstract sense as the heart of commodity production and in its specific organisational forms, for example, trade unions representing workers within systems of production. Early attempts to correct the labour imbalance in GPN analysis were criticised for focusing (as in other academic fields) on labour's isolated success stories at a time of sustained crisis. An attempt to make the analysis theoretically sharper came with Katz's distinction (2004) between resilience (everyday coping practices), reworking (efforts to materially improve conditions) and resistance (direct challenges to capitalist social relations). The question of the balance between acquiescence, resilience, union organisation and local responses to global forces appears in our examination of the engineering services sector. 
Despite the attempts to address the omissions in GPN analysis, for Taylor et al. (2015: 13) there still remains a 'labour process deficit'. Returning to Coe and Yeung's work as the 'state of the art' in GPN theorisation, we note that they point to areas which GPN research is now beginning to address, namely labour supply and - our central concern - the effects of GPNs on labour and labour's agency:

The agency potential of workers is highly uneven across global production networks, depending on whether they perform a strategic role, are effectively able to organize collectively, and are supported in their activities by local institutional and regulatory conditions (Coe and Yeung, 2015: 192).

This is the point of departure for this paper: we argue that these circumstances do frame 'the agency potential of workers' and that, contrary to some strands in recent scholarship in both labour geography and industrial relations, this may explain not a transition to labour internationalism but the stubborn persistence of localism and, at least in the short term, not labour's agency potential but constraints upon it. In short, we do not assume that labour has agency in GPNs. Rather, we pose the question and provide empirical answers.

In developing our argument and analysis, there are quite specific elements of GPN 2.0 upon which we draw. Coe and Yeung (2015: 21) note that early work on GPNs failed to specify the causal mechanisms underlying GPNs themselves and they improve upon this so that GPN theory may better explain uneven territorial development in the global economy. To do so, they focus on capitalist dynamics of 'costs-cum-capabilities, markets, finance and risk' (Coe and Yeung, 2015: 22) while also concentrating on 'value capture trajectories'. Taylor et al. (2015: 7- 
8) build upon this by pointing to three conceptual categories which examine these elements of GPN analysis in depth: value (how it is created, enhanced and captured); power (how it is created and maintained within GPNs); and how agents and structures are embedded in particular territories. These categories, together with Coe and Yeung's fresh insights on capitalism's dynamics are central to how we depict and understand GPNs and labour in this study.

Of particular importance to any analysis of the global resources sector - the empirical subject of this paper - is Coe and Yeung's move away from the focus on single GPNs, which is their definitional starting point, to a consideration of multiple networks. They point to three organisational possibilities: the aggregation of multiple GPNs to form an industry; intra-industry intersection of GPNs through common strategic partners or specialised suppliers; and interindustry intersection of GPNs through firms undertaking different roles in different GPNs (Coe and Yeung, 2015: 61-2). This emphasis on multiplicity is important and, in our case, might be taken to mean that it is worthwhile to think of a 'Rio Tinto GPN' and a 'BHP-Billiton GPN'. Indeed, we suggest that such a conceptualisation of GPNs is essential. Likewise, the two engineering companies on which this paper most concentrates, Komatsu and Caterpillar, based respectively in Japan and the USA, are major global corporations with their own GPNs, competing with each other and intersecting with the mining GPNs as well as interacting with smaller local suppliers. This makes for a 'messier' picture of GPNs but no less an organised one. It is in this context that we seek to make sense of labour in specific industrial and spatial settings.

Focusing on the particular features of any set of GPNs is critical. This is strikingly so in resources related industries such as mining where the mining companies and their suppliers face unusual geographies. Here we draw on Dicken (2011: 243), who argues that GPNs in extractive industries are different from most others because resources are literally embedded, and on Bridge 
(2008), who goes further in emphasising the importance of 'materiality' and 'territoriality'. Materiality brings about a dependency on natural production and limits spatial flexibility while territoriality means that organisations are embedded in the institutional and cultural-political structures of the nation and (in our case) regional states. Extractive industries face specific material limits. It is impossible to move a mine, no matter how much a particular company may wish to. In such instances, exercising control over the state and labour is likely to be more crucial than it is for firms which are more mobile. In this study, the immediate and decisive factor is, however, is how the GPN relationships with suppliers are framed and altered.

In any variety of GPN, though, the state, finance and labour must be accorded more significance than simply being regarded as among the five 'extra firm actors' shaping GPNs. As noted by Smith (2015), discussions of the role of states in GPNs have often centred on policies for creating competitive advantages for places and facilitating 'strategic coupling' between global firms and regional contexts (see also Yeung, 2009). This approach neglects the overall political economies within which processes of capital accumulation are embedded (Stephenson and Agnew, 2016). To this, we add, more specifically, that state-based frameworks to regulate employment relations must also be addressed and this is considered, in relation to the Australian context, later in the paper.

It might be added that, although beyond the scope of this paper, we concur with Coe et al.'s (2014: 762) call for greater discussion of the role of finance. Global financial networks are, they argue, just as globalised and networked as GPNs. Cushen and Thompson (2016: 3) go further: financialisation is a distinct form of capitalism which elevates the significance of financial interests, actors and initiatives and steers management away from investment and value creating activities. 'Downsize and distribute' replaces 'retain and invest'. Cushen and Thompson (2016: 
7-9) suggest that financialisation drives forms of value extraction based on squeezing labour costs and revenues, exacerbates work insecurity and intensification and strengthens punitive performance regimes. We cannot pursue this set of questions in detail here beyond noting that even the managers of resource behemoths like BHP-Billiton and Rio Tinto, whose planning timeframes are necessarily long-term, have come under pressure from major investors and traders as prices fell (McHugh, 2016). As we shall see, the mining companies have imposed on engineering firms precisely the dictates to which Cushen and Thompson refer.

In framing this account, we have drawn, then, on the leading proponents of GPN theory who argue that their approach is indispensable to explaining economic development and on scholars who insist that labour is central to how GPNs develop and that labour is shaped by the dynamics of GPNs. Our primary research questions asked about the drivers of employment relations in the engineering services sector and what role labour played in these GPNs. These questions became all the sharper as our research developed because a global downturn in the mining industry put these very issues at the heart of the actual circumstances facing employers and employees. While this may seem a unique context we argue that, in as cyclical an industry as resources, this merely lays bare the particularly contingent nature of GPN interrelationships. The apparently harmonious relationships between firms and the employers' tolerance for unionism would soon be challenged in this setting.

\section{Methods}

In putting labour as object and subject at the centre of the argument, this paper draws on media, union and business analyses of the nature of, and changes in, the engineering services sector. The study focused on companies operating predominantly in the two major mining sectors in 
Australia, iron ore and coal. The mining industry lies at the heart of Australia's somewhat unusual economy, employing less than two per cent of the paid workforce but accounting for up to 60 per cent of export earnings (RBA, 2012; ABS, 2013).

The most important set of data sources for the paper are interviews with workers, union delegates and union officials as well as managers and supervisors across the three major mining states in Australia (Western Australia, Queensland and New South Wales). In all, we interviewed 109 people between October 2013 and October 2015. The 109 interviews included 11 with fulltime union organisers, 14 with company managers (not including supervisors) with the remainder being with workers. The majority of the workers were qualified tradespeople boilermakers, machinists, electricians, painters, fitters and mechanics. Most of those who were not tradespeople were employees in the stores. The interviews included employees from 13 large companies, 12 of which were multinational. Approximately 60 per cent of the interviewees were employees of subsidiaries of Komatsu or Caterpillar. The interviews were conducted in New South Wales (18), Queensland (42) and Western Australia (49). Additional interviews were completed in Western Australia because the earlier interviews occurred prior to the more serious downturn in the mining sector.

The interviews were semi-structured. The interviewees' responses were often wideranging, this being extremely useful in allowing us to see how they themselves explained their work circumstances, locating them in ways which helped us to see old problems in new ways. The human cost of global downturns was all too real to us in many of these exchanges. These interviews were therefore not easily coded.

The research was funded by an ARC Linkage Grant, with the Australian Manufacturing Workers' Union (AMWU) as the 'Industry Partner'. The union's chief concern was to secure a 
better understanding of precisely the same issue at the heart of the academic debate we are involved in: how GPNs are constituted and the place of labour in them. The sites we visited were at least partly unionised, as has been the norm in bigger plants in this sector. Managers as well as employees, union and non-union alike, gave freely of their time and insights. The research was carried out under a formally approved University ethics protocol.

The development of our empirical research coincided with a major slide in commodity prices leading to a worldwide downturn in employment numbers and mounting cost pressures on suppliers and labour in resource sector GPNs. This particular context drove us to ask fresh questions, as suggested above, about the relationship between firms across GPNs and between mining and engineering GPNs themselves. It also sharpened our focus on the question of labour's agency. This of course has strengths and weaknesses: as we shall show, labour did become a primary consideration, explicitly so, in the minds of the employers and managers whom we interviewed but on the other hand we were assessing labour's agency under trying circumstances. The paper now explains the context of commodities markets before turning to work in engineering GPNs.

\section{The mining industry and GPNs}

Driven by a decline in growth rates in China, prices of mineral resources fell sharply from 2012 on. In the case of the Australian mining industry, although there would have been a decline in employment in any case because many large scale projects were moving from the construction to the process stages, the fall in numbers was spectacular, with for example, over 2000 mine workers in Australia losing their jobs in the first three months of 2016 alone (Ingram, 2016). 
The China-led commodities boom had resulted in the mining sector growing at an average of more than 20 per cent per annum during the first decade of the 2000 s and increasing from 4.5 per cent of Australia's GDP in 2003 to 10.2 per cent in 2013 (BMI Research, 2015: 78). The downturn in both the coal and iron sectors is illustrated in the following graphs of the movements in their prices 2005-2015 which translated into large reductions in revenue.

\section{Figure 1. Coal Thermal, Australian Monthly Price}

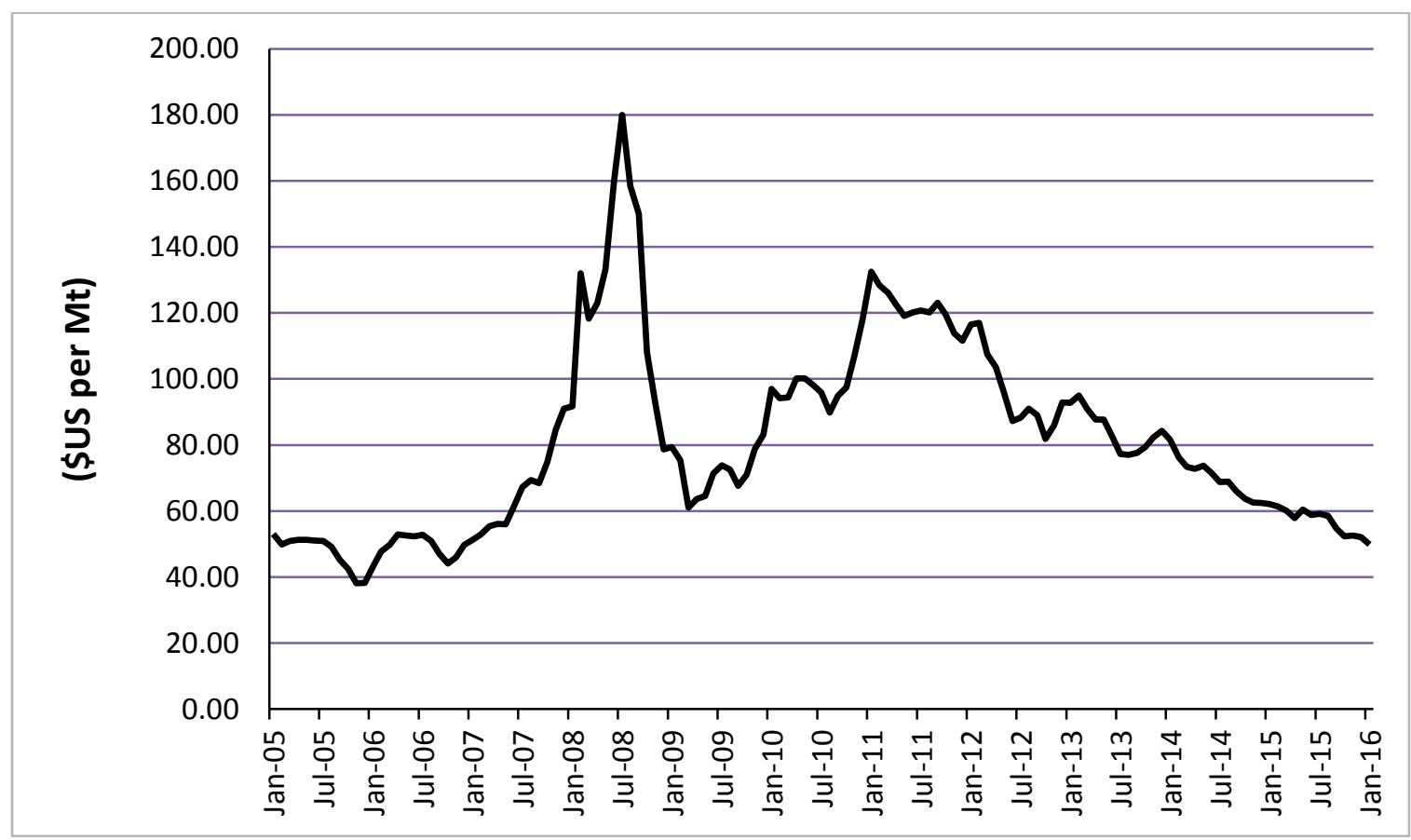

Source: (The World Bank, 2016)

The specificity of different GPNs is also apparent in that the downturn had different timings as between coal and iron ore. As we shall see, localised impacts therefore varied because of the local geography of production, iron ore being mined almost solely in the state of Western Australia, with most coal mining being over 3500 kilometres away in two eastern states, New South Wales and Queensland. 
Figure 2. Iron Ore - Monthly Price

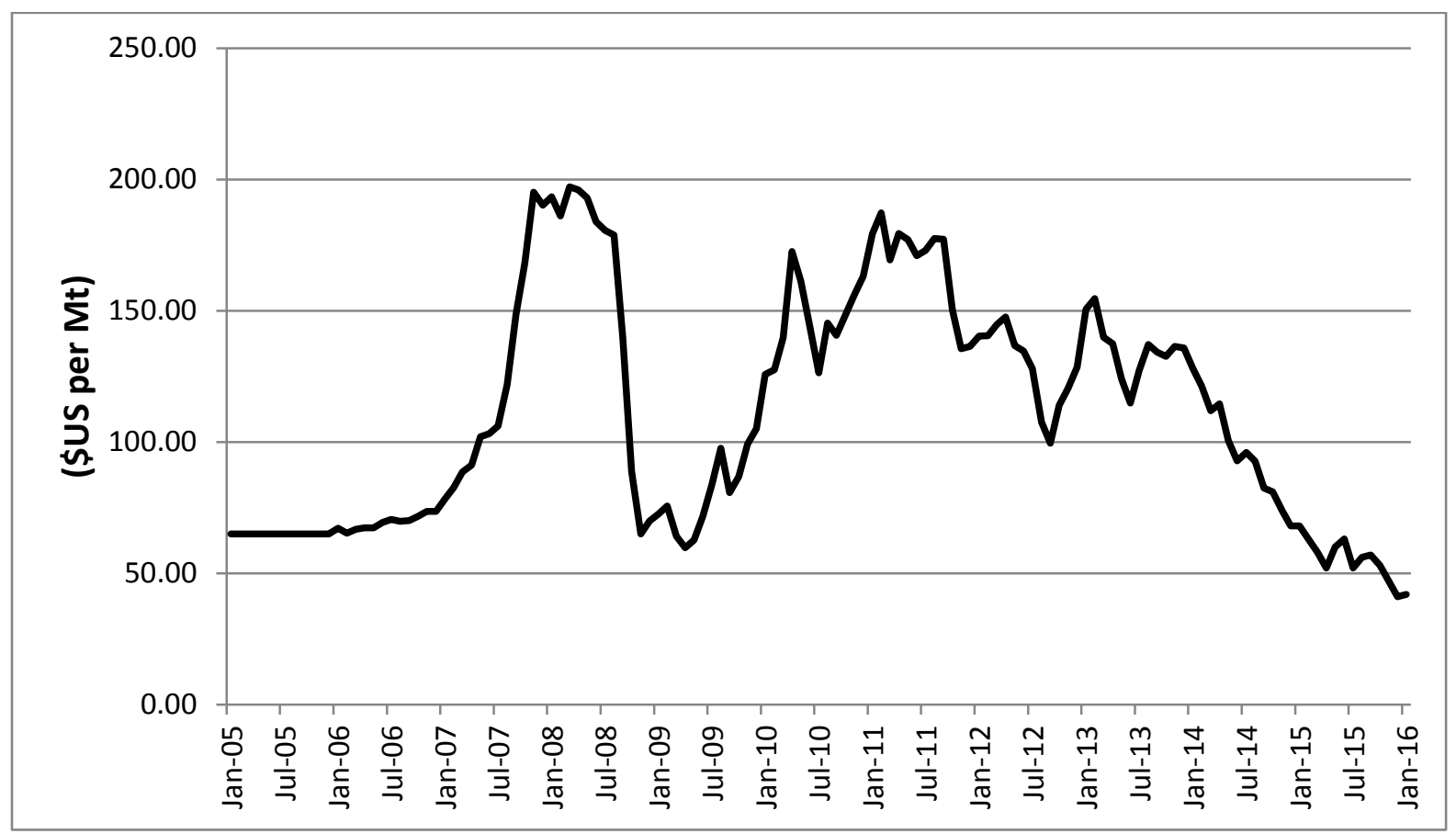

Source: (The World Bank, 2016)

The prospects for the two sectors are also different. Employer responses were shaped in part by how they read the outlook. Despite the downturn, analysts remain optimistic about Australia's iron ore mining future, forecasting Australia's share of global output to increase from 19 per cent in 2013 to 23.7 per cent by 2019 (BMI Research, 2015: 25). This is partly because the cost of producing and shipping high-grade iron ore in Australia is low (Witteveen, 2015). While other mining companies have been suspending production or closing mines, Rio Tinto and BHP-Billiton have been expanding their production, enabling overall lower average production costs and enhancing their market dominance. The prospects for Australia's coal mining industry are less certain. Australia is the world's fourth largest coal producer and second largest coal exporter (Walker, 2015) but is facing serious threats not only in terms of the low coal price and 
the increasing competition from lower cost countries but, over the long term, fundamental environmental challenges (Lucas, 2016).

Turning to the two largest mining companies, BHP-Billiton and Rio Tinto, the following tables detail the loss of revenue and increased production during the downturn.

Rio Tinto Production Performance for Iron Ore \& Coal (Australia)

\begin{tabular}{|l|c|c|c|c|}
\hline & $\mathbf{2 0 1 2}$ & $\mathbf{2 0 1 3}$ & $\mathbf{2 0 1 4}$ & $\mathbf{2 0 1 5}$ \\
\hline Iron ore production (Mt) & 190.6 & 199.9 & 224.9 & 263.0 \\
\hline Hard coking coal (Mt) & 7.9 & 7.7 & 7.1 & 7.9 \\
\hline Semi-soft coking coal (Mt) & 3.3 & 3.9 & 3.2 & 3.6 \\
\hline Thermal coal (Mt) & 20.4 & 22.5 & 21.5 & 18.6 \\
\hline
\end{tabular}

Source: (Rio Tinto Limited, 2015; Rio Tinto Limited, 2016a)

Rio Tinto Financial Performance 2012-15

\begin{tabular}{|l|l|l|l|l|}
\hline & $\mathbf{2 0 1 2}$ & $\mathbf{2 0 1 3}$ & $\mathbf{2 0 1 4}$ & $\mathbf{2 0 1 5}$ \\
\hline $\begin{array}{l}\text { Iron Ore Pilbara Net } \\
\text { Earnings (US\$m) }\end{array}$ & 9,142 & 9,568 & 7,956 & 4,013 \\
\hline $\begin{array}{l}\text { Coal Australia Net } \\
\text { Earnings (US\$m) }\end{array}$ & 402 & 367 & 21 & 48 \\
\hline $\begin{array}{l}\text { Global Product Group } \\
\text { Total Net Earnings (US\$m) }\end{array}$ & 10,228 & 11,334 & 10,215 & 5,445 \\
\hline
\end{tabular}

Source: (Rio Tinto Limited, 2016b; Rio Tinto Limited, 2015)

BHP B Production Performance for Iron Ore \& Coal (Australia)

\begin{tabular}{|l|l|l|l|}
\hline & $\mathbf{2 0 1 3}$ & $\mathbf{2 0 1 4}$ & $\mathbf{2 0 1 5}$ \\
\hline Iron ore (Mt) & 158.9 & 192.6 & 218 \\
\hline Metallurgical coal (Mt) & 29.7 & 37.5 & 42.6 \\
\hline Energy coal (Mt) & 18 & 19.9 & 19.7 \\
\hline
\end{tabular}

Source: (BHP Billiton Limited, 2015) 
BHP B Financial Performance 2013-15 (global)

\begin{tabular}{|l|l|l|l|}
\hline & $\mathbf{2 0 1 3}$ & $\mathbf{2 0 1 4}$ & $\mathbf{2 0 1 5}$ \\
\hline Iron Ore (US\$m) & 18,593 & 21,356 & 14,753 \\
\hline Coal (US\$m) & 6,574 & 6,563 & 5,885 \\
\hline $\begin{array}{l}\text { BHP B Group } \\
\text { (US\$m) }\end{array}$ & 44,636 & 56,762 & 53,860 \\
\hline
\end{tabular}

Source: (BHP Billiton Limited, 2015)

Both companies embarked on significant cost savings initiatives which impacted on those working at the mine sites as well as their suppliers. BHP-Billiton is reported to have cut their iron ore production costs from USD28.0 per tonne to 20.4 during the 2014 financial year (BMI Research, 2015: 69). Rio Tinto had been pursuing an 'emerging markets' global procurement strategy with the central aim of purchasing more lower-cost products from lesser-developed economies (Rio Tinto, 2014). Housing decision-making about key decision like this at a global level, was, in itself a truly important change in the relationship between firms in these GPNs. Both Rio Tinto and BHP-Billiton also embraced automation, a strategy aimed at increasing efficiency and removing risks associated with labour such as skill shortages or industrial action.

\section{GPNs and the downturn: the mining companies}

A central component of GPN analysis is to shed light on the relationship between firms within and across GPNs. For our purposes, the vital issue is to assess these relationships in order to understand labour's place and capacities in those GPNs. The main task of this section of the paper is to therefore examine the relationship between the mining firms and the major suppliers in general and then to assess the impact of the downturn on the mining companies so that we can assess how they reworked their connections with the engineering firms. First, however, we need 
to provide an understanding of the inter-firm relations between the global engineering companies and global mining companies, and to note briefly the internal impact of the downturn on mining GPNs and local labour.

Komatsu and Caterpillar are both truly global players with their own GPNs of manufacturing, dealerships and labour stretching across 180 countries. Returning to our earlier discussion of Coe and Yeung's shift away from focusing on a single GPN to considering how multiple networks aggregate and intersect to form an industry GPN, we can understand that Komatsu and Caterpillar are not only GPNs in their own right but are central nodes in the global mining industry GPN. Caterpillar and Komatsu are the largest suppliers of mining equipment in the world and their top customers include Rio Tinto, BHP Billiton, Vale and Glencore Xstrata.

Thus, if we consider Coe and Yeung's three organisational possibilities discussed earlier, Caterpillar and Komatsu can be understood as specialised suppliers in the global mining industry GPN. Critically, these inter-firm supplier relations are not just arms-length customer relations. These companies are also strategic partners, best illustrated by the current development of autonomous mining equipment. For example, in 2011, Komatsu and Rio Tinto signed a memorandum of understanding to deploy a minimum of 150 autonomous trucks across Rio Tinto’s Pilbara mining sites (Komatsu Ltd, 2011). Similarly, Caterpillar has signed agreements with BHP Billiton and Fortescue to developing autonomous technology in the Pilbara (Diss, 2014). Caterpillar and Komatsu do not just simply supply this autonomous equipment but work directly with mining companies to develop the product, as explained by one Komatsu worker specialising in the autonomous equipment: 
obviously with Rio, it's Komatsu's product but Rio say we want to do this, and sometimes the software, well it's not designed exactly that way, so we've got to modify it or do something to help them [Rio Tinto] (Interviewee 30).

Thus, as noted earlier, the GPN and inter-firm relations we are examining is a 'messy' yet organised picture. These GPN relationships, at least at this strategic level, appear symbiotic, but, as the following section reveals, broader economic forces at times place these strategic partners in conflict.

Turning to the impact of the downturn on mining GPNs and local labour, the mining companies embarked on cost-cutting programs which took multiple forms. Some closed mines while others suspended operations. For example, Glencore Xstrata's closure of its Ravensworth coal mine in New South Wales, Vale's closure of its Integra mines in the Hunter Valley (Holye, 2014; Ker, 2015), Atlas Iron's temporary suspension of its operations at its three Pilbara mines in April 2015 (Thomson, 2015). Many companies reduced the size of their workforces: BHPBilliton cut 230 jobs at Saraji mine in Queensland and reported that they had reduced the number of employees in Australia by 1620 in the 2014-2015 financial year; Rio Tinto cut jobs at its Hail Creek mine in central Queensland (Saunders, 2014).

The mining companies' cost cutting revealed how dependent these engineering companies were as specialised suppliers. The most obvious change was around the purchase of new equipment and changes to maintenance budgets. Reports from the mining engineering companies suggested that these problems were intensified because some mining companies had been extravagant in their purchasing during boom time, 'in 2012-13 companies did things like buying 20 trucks when they really only needed 10' reported one manager from Queensland 
(Interviewee 93). This overcapitalisation, together with the spare equipment due to mine closures, negated the need to purchase new items with the downturn. Furthermore, management in all of the mining engineering companies which participated in the research reported that the mining companies were taking the risk of not doing scheduled maintenance. Evidence quickly emerged of the consequences of this: 'they've had some expensive failures; for example, had they done the scheduled change-out it might have been a $\$ 600000$ cost, had a catastrophic failure I think is about $\$ 1.4$ million; huge, huge cost and that's just one machine' (Interviewee 107).

For the mining engineering companies, these changes meant a huge reduction in work. In addition, the management of the work which remained was now more difficult. Planning was easier when mining companies abided by their regular maintenance schedules:

Previously work was booked up for a whole year, 2011-2012; now we don't know what work will be available beyond 2 weeks. Most work previously came from the Hail Creek Rio mine but now have to tender everywhere. (Interviewee 90)

One manager of a mining equipment company reported that the mining companies were now auditing the costs of the service companies:

If we blow the quote, we can't go back to them and say ... [But] say we put in a thousand hours [into the quote], they come and audit and find that we did it in 700 hours, they'll want their 300 hours back (Interviewee 66). 
More generally, the nature of the relationships between the mining companies and their suppliers had changed. The past behaviour by the mining companies, where they preferred to obtain their parts from the Original Equipment Manufacturer (OME), for example, Komatsu and Caterpillar subsidiaries, could no longer be assumed. The mining companies now demanded cheaper parts, prices and labour rates. They put some jobs out to fresh tender, driving much more competition within the mining engineering services sector. These feelings were summed up thus:

Customer loyalty is a bit out the window these days ... We can't rely on past relationships. We can try and build on them ... but because the mines are so tight, as it is similar to suppliers to us, people that we've worked with for a really long time, if they can't do it at the best price for us, we have to look elsewhere as well (Interviewee 53).

As one Rockhampton interviewee from one of the major companies serving the Queensland coalfields commented when asked about the influence of the mining companies: 'They're feeding back to us that they can't afford [our company]. "We can't afford to do business with you anymore". That's the line that the mining companies are pushing' (Interviewee 102).

In sum, the downturn illustrated how inter-firm relations within a GPN change over time and are influenced by the economic context. The downturn also elucidates labour's position within the context of GPN relationships. That is, as these inter-firm relations come under tension it is labour that occupies a central position. Even in capital-intensive industries, labour may be seen as a large part of the problem and therefore labour is a significant focus of the solution in reducing the labour force or forcing engineering services to reduce servicing labour costs. The 
following sections bring labour's position within GPN relations to the fore by highlighting the response of engineering services companies and then the response of organised labour itself.

\section{GPNs and the downturn: the engineering companies' responses}

The socio-spatial nature of GPNs, specifically local variation, was clear because of the geographical concentration of the coal and iron ore sectors in different places. The downturn in the mining industry affected different regions and companies in different ways. This was reflective of, as this section shows, the availability of capital, company size, the specifics of the coal as against the iron ore downturn and previous levels of efficiency in particular firms and places.

Nationally, the picture was bleak. Austmine's surveys of the Mining Equipment, Technology and Services sector in Australia reported that in 2015, 79 per cent of the respondents reported a decrease in revenue compared with 23 per cent in 2013. The average decrease reported was 31 per cent. No less than 61 per cent of respondents reported a decrease in profitability; 59 per cent reported a decrease in customers and projects; 52 per cent reported a decrease in employee numbers compared with 22 per cent in 2013 (Austmine, 2013, 2015).

Companies and workplaces servicing the coal industry were affected ahead of those linked to the iron ore industry. Our research in the Hunter Valley (the major coal mining region in New South Wales) revealed a very depressed mining engineering services sector with a bleak picture of large-scale redundancies and no prospects of employment. This contrasted with the research visits in Western Australia immediately preceding this where the flow of work in the engineering services companies had still been reasonably strong, albeit reduced from the boom. 
Smaller locally-owned companies in the Hunter region which did not have the capital to sustain themselves through this crisis were either being purchased by larger - often foreignowned - companies or closing up. Interviewees from two companies reported that their formerly locally owned companies would not have survived if they had not been purchased by their new overseas owners but in both instances the change of ownership was resulting in manufacturing work being sent offshore (Interviewees 54, 67).

OEM subsidiaries of companies such as Caterpillar and Komatsu had a stronger financial base to support them, although the impact of the industry downturn differed between and within the companies. Workforce levels had been managed more tightly prior to the downturn in one company and less so in another, with the consequence of far higher and more immediate redundancies in the latter. One manager from that company reported that in 2013 with only half the number of employees they had produced the same number of components as had been produced previously (Interviewee 69).

The downturn in demand combined with the pressures to be more competitive by lowering their prices was resulting in other measures to increase efficiency: increased measurement of productivity, improved forecasting, issuing invoices more promptly; improved waste minimisation; greater checks on purchasing; and the introduction of a new centralised call centre aimed at consolidating a range of functions (Interviewees 69, 69, 72, 73, 79, 88, 97).

Unsurprisingly, then, the main response by the mining engineering services companies to the downturn was to cut costs. All of the worksites visited in our research had reduced the size of their workforces, most commonly through a combination of natural attrition and redundancies. In the Hunter region there were examples of much wider layoffs: 'If we go back four years ago, we had over 270 people working over... at the... site. Right now they are down to 16' (Interviewee 
57). Another reported: 'we've hit about yeah, about 970 and I think we're down to about 350 now' (Interviewee 58).

In Queensland, one of the large mining engineering services companies had reduced its workforce by approximately 30 per cent while another large firm had downsized by approximately 10 per cent (Interviewees 78, 83, 105). A senior manager at the latter company expressed the dilemma he felt about making staff redundant:

Our current technician staff level is probably higher than we really should have if you just looked at it from a financial perspective but we spent so much money developing these people, they've been loyal to us as well, so we're trying to hang on to them.

He also expressed his concerns about the reductions in their intake of apprentices, from more than 20 down to three or four. Once again, his dilemma reflected the tension between cutting costs and potentially jeopardising their future skill base: 'You'd rather be putting on apprentices, it just works so well, developing your own people and they come out of it with the [company's] blood pumping through their veins and experts on your gear' (Interviewee 107).

The downturn resulted in the use of casual contracts when extra labour was required, where previously management would have preferred permanent employment:

[One firm] is advertising for casual plant mechanics, first time in 30 years use of casuals. Hunter Valley have used contract people last couple of years to assemble trucks. Company policy was previously anti-contract because more expensive and issues about training and upskilling (Interviewee 93). 
Along with cost-cutting came greater control. Management seemed to be using performance appraisal or review mechanisms in fresh ways to determine who was to be made redundant. The level of specificity in the performance measure varied, giving management wide scope to exercise choice. At a plant in Western Australia where two prominent union delegates were made redundant, a remaining delegate reported that the criteria in the performance matrix were 'very, very easy to manipulate' (Interviewee 45). His perception was that if a manager:

has a grudge against you they can mark you down as they see fit. And there was very little avenue for redress with that.... The guys that got made redundant were guys that had medical conditions, guys that stood up for themselves and basically anyone of any major union input. Why I'm still there I have no idea.

Labour costs were cut in most of the workplaces by changing rosters and reducing hours. The afternoon shift was cancelled in one Queensland plant, overtime was being avoided in most plants, and one company had closed its plant for two weeks over Christmas for the first time ever. The pressure on the engineering companies from the mining companies was felt here too, with their refusal to include penalty rates or overtime payments in the calculation of labour costs by the engineering services companies, hence the latter's attempt to eliminate or at least minimise these (Interviewee 107). Management and union interviewees also recounted attempts by management to negotiate reduced labour costs in their bargaining of new enterprise agreements or in variation to existing ones. Examples included reduction or removal of 
allowances (Interviewees 69, 71) and attempts to vary agreements to remove agreed wage increases (Interviewee 41).

To sum up: the impacts of global change varied across local economies but typically included the demise of smaller local companies and intense cost cutting in all the engineering companies: fewer hours, different rosters, EBA negotiations, workforce reductions, tension between retaining own-trained and permanent workers as against using contract labour 'as and when'. In short, labour - understood as local labour markets and labour processes - was the object of transformation in these GPNs. What did this mean for workers themselves?

\section{Labour and GPNs}

The actions of management in the mining and mining engineering services companies directly impacted on labour. In contrast to these networks, it should be noted at this point that there was little connection between organised labour in the mining engineering services sector and the mining sector. The main unions organising workers at the mine sites (the Construction, Forestry, Mining and Energy Union and the Australian Workers' Union) differ to the union organising workers in the mining engineering services sector (the AMWU). A successful drive by mining employers in Western Australia to shut unions out of the iron ore mining sector meant that at the time of our study there was minimal union presence at the Western Australian mine sites. The shutting out of organised labour underscores a critically important point: labour in the Australian mining industry has come under sustained attack in good and bad economic times. This is particularly the case in the iron ore industry where unionism was almost eradicated (Ellem, 2015), but even unions in the coal sector have been engaged in defensive campaigns of survival for 20 years (Hearn Mackinnon, 2007). In addition, mining work was typically located in 
isolated sites while the bulk of the mining engineering services work was distanced from them because it was located in urban and regional centres. Labour was therefore fragmented by geography, history and union structure.

Labour's options and responses were affected by the state's highly interventionist labour regimes. In particular, regulatory reforms in Australian industrial relations made by successive governments over the previous two decades were important in shaping what the union did. The changes most relevant to this research have been the move away from industry to enterprise bargaining together with the high level of restrictions imposed on the taking of industrial action and on union militancy in general. Since the 1990s, state and national conservative governments had placed ever more stringent limits on the effective right to strike and the current legislation, the Labor Party's Fair Work Act of 2009, had done little to reverse this. The enterprise bargaining focus, apart from occupying an inordinate amount of union officials' time and resources, encouraged a very localised, workplace-based focus upon what was an industry-wide downturn. And the restrictions placed on industrial action confine legal industrial action to a deemed period around the negotiation of an enterprise agreement, thereby virtually eliminating the option of taking any form of industrial action in response to management's actions during the downturn in mining.

Labour's ability to respond was constrained and shaped by other factors including the labour market, regulation, corporate strategies and socio-political forces. In terms of the labour market, there was a major swing from a serious shortage of skilled labour to a situation where supply exceeded demand. A mining engineering services manager at Rockhampton (Queensland) commented: 
previously [there was a] manpower shortage; mining was paying anything to get work done. I recruited in Africa, England, Philippines ... put on 41 apprentices in one year, 20 and 30 in prior years. It was also hard to get good apprentices as they were getting highly paid unskilled jobs on the mines ... Never seen anything like it, never thought I'd have to make people redundant (Interviewee 89).

Prior to the downturn there had been substantial use of labour hire and recruitment of '457s', a visa category for temporary immigrant workers filling skill shortages; however, by the time of our research visits few labour hire or 457 workers remained. The change in the workforce composition at one of the large engineering services companies in Queensland exemplified what occurred at a number of the sites: at the peak there had been approximately 150 workers on sites, about 40 of whom had been labour hire. With the downturn, the onsite workforce had decreased to $80-85$ and no labour hire workers were present (Interviewee 80).

At one large site in Queensland, there was still a small number of 457 workers employed. Their ongoing employment was a source of friction between management and some of the local workers. The workers resented the fact that 'Australian workers' had been made redundant while some $457 \mathrm{~s}$ retained their jobs. In (a familiar) contrast, the manager described them as working harder than their local counterparts. Perhaps more interestingly, he said he was very aware of the difficult personal circumstances of some of the temporary visa holders: 'They bring family; one South African had brought his wife and two-year-old to the country only seven days prior [to the company's redundancies]' (Interviewee 69). Management also reported low turnover as job opportunities elsewhere were minimal (Interviewee 93). 
Job security was a major issue for some interviewees, but not for all of them. The response was shaped by geography and by job role. In one region already facing recession, the Hunter Valley, there was a feeling of hopelessness amongst all interviewees about the collapse of the mining engineering services industry. Given the generally precarious nature of the coal industry, they could not see employment possibilities in the future. In the state of Queensland, interviewees' responses were more diverse. Several supervisors indicated that they felt very insecure and that this concern permeated all in the industry including management. Comments from workers concerned about their ongoing employment included:

We don’t have job security at all...There's no guarantee of your job and people are going to be put off. To my way of thinking ..., if they're going to put people off, they're going to do it whether we drop [i.e. concede in the EBA negotiations] or stay up where we are. (Interviewee 101).

Others were still more succinct: 'No. There's a feeling that tomorrow they could just shut the doors and it'd be over. There's not even the certainty that we'll get anything from it either' (Interviewee 104). One response bleakly summed it up: 'You just never know' (Interviewee 79).

Some workers did feel more secure either because they believed that their jobs were essential for the company to continue operating or because they perceived their employer as having completed the redundancy process and that no further redundancies were likely. Several interviewees who worked in the parts area of their workplace concluded that 'they always need parts' and therefore that if there were to be further redundancies that they would be elsewhere. Similarly a specialist tradesperson reported that the company could not afford to be without him 
as no one else had his particular skill. Some interviewees went as far as to express a general acceptance of redundancies. For example, one interviewee claimed that as the 'writing was on the wall that people had to go' employees did not question it (Interviewee 72). Another interviewee was unsympathetic to those made redundant in her section: 'The four who went were not helpful, unpleasant, so most were not concerned about them being made redundant' (Interviewee 84).

The same diversity of responses to job insecurity was evident in Western Australia. At one site where there had been a wave of redundancies in 2015 , one interviewee claimed that employees were shocked by this and that morale was very low as a consequence, while another who had been made redundant declared himself to be much happier in his new job with a competitor in the same industry (Interviewee 49).

Many workers had had their income reduced. For example, an employee working in the warehouse of one large company had been working two hours of overtime every day which had been removed, resulting in a drop in her pay of approximately $\$ 200$ per week. A tradesperson reported a pay decrease of approximately $\$ 30000$ during the past 12 months due to the reduced hours and shifts. While the reduced hours reflected the downturn in work, some interviewees cited work intensification, complaining that management expected the same volume of work to be completed in reduced hours (Interviewees 68, 87).

These responses make very plain, as Katz (2004) argues, that response and agency itself need to be closely interrogated. These interview responses mostly lay, in Katz's terms, between 'acquiescence' and 'resilience', the balance between them being shaped, apart from personal traits, by perceptions of general economic trends and local labour market prospects. In either case, the responses quite quickly became individualised, even if workers (or ex-workers) had 
common experiences of insecurity and unemployment. These limited forms of what might be called individual agency both led to and resulted from how workers read the scope for 'reworking' and 'resistance' through organised labour.

The global downturn and the subsequent national and local management actions posed major challenges to the union representing the engineering service workers, the AMWU. This union was particularly important because for many years its wages and conditions provided the benchmark for other sectors and in the 1980s, it led the way in attempting to create a Nordicinspired 'strategic unionism' to adjust to threats to manufacturing in high-wage economies. The union had been weakened, however, before the mining downturn, partly because of the collapse of vehicle production in Australia (Sheridan, 1975; Balnave and Patmore, 2013).

The union officials and activists to whom we spoke certainly believed that the severity of the most recent downturn in the mining industry had revealed limitations in their capacity to defend their membership. There were, of course, differing views about this and the actions of the union spoke of attempts to exercise agency by at least retaining the conditions they had been able to seize in the global boom. The local unevenness of unionism in the sector was a significant element. Union density varied considerably across the industry and between places. Some workplaces were highly unionised and others had virtually no union presence, even within the same town or city. This paper cannot explain this historically-informed phenomenon but we do explore its impacts, beginning with the way in which job losses played out in reducing support for, or belief in, the union's effectiveness.

An overarching aspect of the downturn was that redundancies not only reduced the number of fee-paying union members but undermined union workplace structures: 'We had a really decent delegate structure there, we actually had one of the delegates there work for us for 
some time after he was made redundant. But through all the redundancies, our membership...has been smashed' (Interviewee 50). Two leading delegates were made redundant in a major Western Australian plant while an interviewee at a unionised plant in Mackay (Queensland) complained that their senior delegate (a role akin to shop steward in the UK) had been made redundant. This undermined communication from the union to members and the effectiveness of worker representation in dealing with management. A key interviewee in this workplace reported that he did not believe that the delegate had been dismissed because of his union activity but the impact was clear: workers were afraid to volunteer to be union delegates (Interviewee 90).

Job losses also affected worker loyalty to the union as would be expected given the prevalence of individualised acquiescence we have reported across the country. One AMWU organiser revealed the extent to which the leadership already felt constrained, commenting that 'a lot of people have unrealistic expectations about what the union can do' (Interviewee 71). In a similar vein, a delegate stated that workers: 'were devastated with the redundancies; I think they thought we could somehow save them and, as delegates, we hope that too. But unfortunately we couldn't' (Interviewee 46).

A vicious cycle was developing, long familiar in discussions of union power. Because the union could not (or certainly did not) prevent widespread redundancies, it appeared all the more powerless. One pro-union worker in a once heavily unionised site said that: 'the redundancies showed that the union couldn't really do anything' (Interviewee 103). Another, that 'those made redundant weren't helped by the union, for example, to find other work' (Interviewee 104). More broadly, some interviewees explained declining membership in their workplaces in terms of lack of support from the union. In one workplace where interviewees suggested that union density had declined from 90 per cent to approximately 50 per cent, a senior member stated: 'Most of 
them are saying they're not getting value for money. You're paying over five hundred bucks a year and...what do you get out of that?' (Interviewee 103).

In this unsettled context, workers began to articulate criticisms that in buoyant times would be less common. For some, the union was only visible when it was time to renegotiate the local agreement (Interviewees 75 and 105); for others the union 'protect[ed] bad employees, the ones you don't really want to be working with' (Interviewee 98). Another interviewee had cancelled membership, feeling a loss of trust:

And throughout that time, as bad as it sounds, they preach that they're tough and strong and they're there to do everything but I haven't seen them do much yet. All the guys who lost their jobs with all the redundancies, they weren't helped out in finding another job. It was just like, 'oh, sorry guys', and that was it...I know they're constantly trying to fight for something better with the EBAs [local collective agreements], but constantly fighting EBAs and knocking it back, knocking it back, eventually it's going to go round full circle and we're going to lose out (Interviewee 104).

Many other interviewees still viewed the union favourably:

I've always been in the union. I just thought it's better off to be in a union than not be in a union. You've got a bit more support and a bit more back up if something does go wrong. It's probably better...I suppose safety in numbers and things like that (Interviewee 94).

Another also reflected on the general importance of belonging to a union: 
It makes me sad that the union membership at this place isn't as high as it could be potentially. We're all workers working for one cause, working under one enterprise agreement, and it's my opinion that everyone should be part of the union...there's more value in it than just the enterprise agreement and that sort of thing. There's all that other stuff that the union does for people that they don't really understand (Interviewee 102).

Other workers commented on the union's involvement with agreement negotiations (Interviewees 72, 73), the union fighting for what workers want (Interviewee 68) and the union's role in communicating with management on behalf of the workers (Interviewees 84, 97). Among other things, it is striking (albeit beyond the scope of this paper) that even in this union, with a deep tradition of member involvement and, like many unions in the UK and the US, 20 years of 'organising' strategies, it was more common than not to speak of 'the union' as an entity distinct from the members themselves.

For their part, union organisers were frustrated by the national regulatory framework in which they were trapped. They believed that this curtailed the organisation's ability to act for its members. This predated, but was made very clear by, the mining downturn. The negotiation of enterprise agreements - sector level bargaining being a thing of the past - was particularly debilitating because it was time-consuming and reduced the opportunity to engage in organising or more strategic activities (Interviewees 96, 100). More specifically, responses to management actions were constrained by the strict limits placed on strikes and other forms of industrial action. In short, the union's leadership felt very acutely that any response to redundancies was limited 
by the economic context which had led to job losses, by the bargaining regime and by other legal constraints.

In dealing with the immediate issue of job losses, the union leaders and activists felt that they could do little beyond monitor the application by management of the (agreed) criteria:

Every redundancy we've had...we've had a good procedure, where there's been abilities for disputes, it's been a fair and transparent process. Others where you might have a weak consultation clause in the agreement, you sit down, you go through the skills matrix or how the company may assess the workers, but you don't get any input into it, you only get to know how they're going to do the assessments. And nine times out of 10 the assessment process is so subjective that there's just no way to argue a fair and transparent process within it, it's just basically you cop what you cop, and you get told how it's done but you just have to wear it. And that creates a sense of feeling like they can't do anything about it amongst the workforce (Interviewee 50).

The subjective nature of some of the criteria prevented the union from being able to challenge formally when they believed that members had been targeted for redundancy because of their union activities (Interviewee 46).

In considering the experiences of labour, it can be observed that there was a degree of commonality in the attitudes and perceptions of all interviewees regardless of their roles. All recognised the global nature of the downturn and did not see themselves as being able to impact the forces driving the downturn. Pessimism and insecurity were displayed by workers, union delegates and union officials and unsurprisingly many focused their disgruntlement upon 
management decision making. There were, however, differences in their perceptions relating to the region in which they were located. There was much greater pessimism about the future of the industry, and more specifically the potential for future employment, amongst the interviewees in New South Wales. Given the enormity of the redundancies combined with the apparent restructuring of the work with jobs being relocated offshore often within the company, the future looked bleak. In Queensland, while there were some concerns about the long-term future of the coal industry, there was no reported evidence of relocation of work so the downturn was viewed as cyclical. Similarly, in Western Australia, most viewed the developments as part of the mining industry cycle and expected iron ore mining to continue to provide opportunities for the foreseeable future.

The role of a union to advocate on behalf of members and at the very least to protect their existing conditions shaped the experience of the union delegates and fulltime officials somewhat differently to that of the workers. Union delegates and officials recognised their impotence in protecting their members' jobs and conditions of employment. Some reacted defensively, observing the unrealistic expectations of members. And then for workers, their experience of the changes brought with it the realisation that neither management nor the union were able to support them with the challenges they were facing in their continued employment or potential unemployment. In sum, the industry-wide nature of the market downturn meant that there was a large degree of commonality in the experience of labour, regardless of their role, but at the same time their geographical location and role shaped their personal experience of the changes.

Finally, in responding to personal and local uncertainty as change washed through these GPNs, labour's scale of response was geographically limited. Union organisers spent most of their time dealing with the impact of individual redundancies or the intricacies of enterprise 
bargaining. The opportunity cost of this was that they had, in their own estimation, too little time to think and act beyond these immediate workplace issues. There was no obvious indication of interstate collaboration between union officials organising within the same company. Similarly, employees themselves were very local in their focus; their understanding was confined to their own workplace and towns. As we have seen, local union interviewees (in many ways like local managers) were very aware of how the downturn was affecting their own region. This was particularly in smaller towns, with narrower regional economies where there was genuine fear:

I've seen an increase in the Hunter area of things that occur from job losses. Such things as you know, crime rates are going up, families dividing through maybe financial constraints of lack of job stability. I've seen ... people having to essentially live out of cars in some circumstances, seen increases of mental illness occurring, you know, with that I see things like suicide are occurring, depression, anxiety. You know, there's a whole host of things that come from this terrible time ... it's not just ... jobs, it's a much broader thing (Interviewee 51).

Plainly, then, the accommodative and coping responses of workers, the national regulatory space and regional economies all worked with the already constrained capacity of the union to close down much collective agency at this time. The union barely reworked, let alone resisted, as Katz has it, the imperatives of capitalist social relations while, as members saw it, at the local scale, mining and engineering GPNs all but imploded around them. As important as labour power was to the GPNs, it was plain that, individually and collectively, its agency was 'constrained' (following Coe and Jordhus-Lier, 2011) by the geography of those GPNs and by the specific 
nature of global recession. Labour was central to how the downturn played out but did not exercise collective agency.

\section{Conclusion}

In making plain the global nature of production and in taking its networks, not national economic spaces, as the starting point for analysis, GPN theory seeks to explain economic change in general and particular aspects of trajectories of development. As many have noted, however, GPN's approach to the question of labour remains underdeveloped. Taking labour seriously as a source of value in GPNs is a first step, the importance of which is widely accepted. How labour acts in shaping GPNs is a further question which other scholars have insisted should be addressed.

Our examination of mining engineering services GPNs revealed that the sector in Australia and perhaps, in this case, the national economy itself were deeply subordinated to the global, in both buoyant and troubled economic times. As global commodity prices fell, BHPBilliton and Rio Tinto began to cut costs in their own operations and, while doing so, wielded significant power over other global firms such as Komatsu and Caterpillar as well as smaller, local firms which were still less well-placed to absorb costs and pressure. Long-term relationships counted for little as global pressures mounted. There were marked downturns in engineering GPNs and recessions in some local economies. Labour processes, local labour markets and even regional economies were reconfigured. In short, labour was a central object in mining and engineering firms' responses to the downturn and in the reconfiguration of these networks. One of the key reasons for this was the inter-firm relations in these sectors: the engineering firms were heavily reliant on mining, having few alternative networks with which 
they could connect. They, and their workforces, were more markedly affected by the mining downturn than other sectors of the national economy.

Labour's agency potential was therefore limited in this setting. The nature of the response which we read, following Katz (2004), mainly in terms of acquiescence, was striking in itself. It was also one factor in explaining the limited nature of the collective response. This response needed to be situated in a wider context, beyond individuals and workplaces, to be fully understood. Nation states and local economies were, as many insist, important in shaping labour's agency. Long term changes to the structure and location of work had, for many years, as in other 'advanced' societies, threatened the capacity of unions such as the AMWU to defend members but these trends were markedly exacerbated by the state's actions. This is an important theoretical point: the forms of local regulation to which Coe and Yeung (2015) briefly refer were indeed critical to the more immediate fragmenting, localising and disempowering of labour as the resources boom faltered.

That the state must be accorded a role in GPN analysis is very clear from this paper: an assault on unions through legislative and other means is a well-established element of this but so too recognising the impact of a particular system of agreement-making which is time-consuming, localised and resource-intensive and enmeshed with laws which limit lawful strike action. Local agency in response to globally driven change was therefore circumscribed and was constituted largely at the individual level.

This leads us to suggest - and here further research is needed - that just as scholars may have overlooked the role of labour in GPNs, so might they have failed to examine in sufficient depth how GPNs were reshaping work in particular places in ways that were obscured by boom times. Even under those circumstances of growth, in the advanced economy examined here, 
organised labour exercised relatively little power for itself, far less for workers in other countries, that is, in other parts of these GPNs. Labour's generalised weakness in these GPNs was made all the clearer when circumstances changed, specifically with a global commodity downturn.

GPN analysis can be powerful, the more so, we have tried to show, when labour is foregrounded and the nature of local geographies and national states woven into empirical investigations of how GPNs work. Lead firms in GPNs focus on labour while labour's capacity to respond is heavily shaped by those very GPNs and by national and local structures. Situating all this still more fully in the geographies and finances of global production, while assessing labour's role at the global scale, are further steps to be taken in empirical work.

\section{Acknowledgements}

The authors would like to acknowledge the support of the project's research partner the Australian Manufacturing Workers' Union. We are deeply grateful to the journal's editors and referees whose feedback required a productive sharpening of some of the empirical details in the argument and the conceptual contribution our paper was seeking to make.

\section{Funding Acknowledgement}

This work was supported by the Australian Research Council (Linkage Project Number 130100718).

\section{References}

ABS (2013) Cat. 8155.0, Australian Industry, 2011-12, 28 May, ABS, Canberra. 
Austmine (2013) Australia's new driver for growth: Mining Equipment, Technology and Services. Available at: http://www.austmine.com.au/Portals/25/Content/Documents/Austmine\%20Survey\%20Hi ghlights.pdf.

Austmine (2015) New Realities, Bigger Horizons: Australian Mining Equipment, Technology and Services (METS) National Survey. Available at http://www.austmine.com.au/News/articleType/ArticleView/articleId/2724/NationalMETS-Survey-2015-Results-New-Realities-Bigger-Horizons.

Balnave N, Patmore G (2013) The AMWU: Politics and industrial relations, 1852-1920. In: Reeves A, Dettmer A (eds) Organise, Educate, Control: The AMWU in Australia 18522012. Clayton: Monash University Publishing, 3-33.

BHP Billiton Limited (2015) BHP Billiton Resourcing Global Growth Annual Report. Available at: http://www.bhpbilliton.com/ /media/bhp/documents/investors/annualreports/2015/bhpbillitonannualreport2015_interactive.pdf?la=en.

BMI Research (2015) Australia Mining Report Q3. London: Business Monitor International.

Bridge G (2008) Global production networks and the extractive sector: governing resource-based development. Journal of Economic Geography 8(3): 389-419.

Coe N and Jordhus-Lier, D (2011) Constrained agency? Re-evaluating the geographies of labour. Progress in Human Geography 35(2): 211-33.

Coe N, Lai KPY and Wójcik D (2014) Integrating Finance into Global Production Networks. Regional Studies 48(5): 761-77.

Coe N, Yeung HW-C (2015) Global Production Networks: theorizing economic development in an interconnected world, Oxford: Oxford University Press. 
Cumbers A, MacKinnon D and Shaw J (2010) Labour, organisational rescaling and the politics of production: union renewal in the privatised rail industry. Work, Employment \& Society 24(1): $127-44$.

Cushen J and Thompson P (2016) Financialization and value: why labour and the labour process still matter. Work, Employment \& Society 30(2): 352-65.

Dicken P (2011) Global Shift: Mapping the changing contours of the world economy, London: Sage.

Diss K (2014) Robotic Trucks Taking Over Pilbara Mining Operations in Shift to Automation. Australian Broadcasting Corporation. Available at: http://www.abc.net.au/news/2014-0425/computer-controlled-trucks-taking-over-in-pilbara-mining-wa/5412642.

Ellem B (2015) Resource peripheries and neo-liberalism: The Pilbara and the remaking of industrial relations in Australia. Australian Geographer, 46(3): 323-37.

Hearn Mackinnon, B (2007) Behind WorkChoices: how one company changed Australia's industrial relations, Melbourne: Heidelberg Press.

Holye R (2014) Glencore to close Ravensworth coal mine in NSW. Available at: http://www.theaustralian.com.au/business/mining-energy/glencore-to-close-ravensworthcoal-mine-in-nsw/story-e6frg9df-1226866370046.

Ingram T (2016) 2000-plus mining jobs cut in 2016; more to go. The Australian Financial Review. 7 March, p.13.

Katz C (2004) Growing up global: Economic restructuring and children's everyday lives, Minneapolis: University of Minnesota Press. 
Ker P (2015) Vale posts fourth-quarter loss of \$US1.85b on iron-ore price plunge. Available at: http://www.smh.com.au/business/mining-and-resources/vale-posts-fourthquarter-loss-ofus185b-on-ironore-price-plunge-20150226-13q7dn.html.

Komatsu Ltd (2011) Komatsu \& Rio Tinto Enter into Agreement for 150 Autonomous Truck Deployment into Pilbara Iron Ore operations by 2015. Available at: http://www.komatsu.com/CompanyInfo/press/2011110210131401750.html.

Lucas A (2016) Stranded assets, externalities and carbon risk in the Australian coal industry: The case for contraction in a carbon-constrained world. Energy Research \& Social Science 11: 53-66.

McHugh B (2016) Iron ore price heavily influenced by trading as well as supply and demand says industry veteran. Available at: http://www.abc.net.au/news/2016-02-24/iron-ore-price-and-spot-price-trading/7193318.

RBA (2012) Statement on Monetary Policy-May: Box C, Reserve Bank of Australia, Canberra. Rio Tinto Limited (2014) Creating a secure and sustainable supply chain. Available at: http://www.riotinto.com/sustainabledevelopment2013/economic/suppliers.html.

Rio Tinto Limited (2015) 2014 Annual report. Available at: http://www.riotinto.com/ar2014/pdfs/rio-tinto_2014-annual-report.pdf.

Rio Tinto Limited (2016a) First quarter operations review. Available at: $\underline{\text { http://www.riotinto.com/documents/160419_Rio_Tinto_releases_robust_first_quarter_pr }}$ oduction_results_(1).pdf.

Rio Tinto Limited (2016b) Rio Tinto 2015 Full Year Results. Available at: http://www.riotinto.com/documents/160211_Rio_Tinto_2015_full_year_results.pdf 
Saunders A (2014) Rio Tinto to cut jobs at Hail Creek mine. Available at:

http://www.smh.com.au/business/mining-and-resources/rio-tinto-to-cut-jobs-at-hailcreek-mine-20140501-37kck.html.

Sheridan T (1975) Mindful Militants: The Amalgamated Engineering Union in Australia 19201972, Cambridge: Cambridge University Press.

Smith A (2015) The state, institutional frameworks and the dynamics of capital in global production networks. Progress in Human Geography 39(3): 290-315.

Stephenson SR and Agnew JA (2016) The work of networks: Embedding firms, transport, and the state in the Russian Arctic oil and gas sector. Environment and Planning A 48(3): $558-76$.

Taylor P, Newsome K and Bair J (2015) Putting labour in its place: labour process analysis and global value chains. In: Newsome K, Taylor P and Bair J (eds) Putting Labour In Its Place : Labour Process Analysis and Global Value Chains. London: Palgrave Macmillan, 1-26.

Thomson J (2015) Atlas Iron to shut mining operations due to price plunge. The Sydney Morning Herald, 11 April, p.4.

Walker S (2015) Coal: Responding to Structural Change. Engineering \& Mining Journal 216: $58-68$.

Witteveen B (2015) Resources and Energy Quarterly. Dapartment of Industry and Science (ed). Canberra: Commonwealth of Australia, p.18-23.

The World Bank (2016) World Bank Commodity Price Data (The Pink Sheet). Available at: http://www.worldbank.org/en/research/commodity-markets. 
Yeung HW-C (2009) Transnational corporations, global production networks, and urban and regional development: a geographer's perspective on multinational enterprises and the global economy. Growth Change 40(2): 197-226. 